\title{
Sensing of Alzheimer's Disease and Multiple Sclerosis Using Nano-Bio Interfaces
}

Mohammad Javad Hajipour ${ }^{\mathrm{a}, \mathrm{b}, \mathrm{c}}$, Forough Ghasemi ${ }^{\mathrm{d}}$, Haniyeh Aghaverdi ${ }^{\mathrm{b}}$, Mohammad Raoufi,e, Uwe Linne $^{\mathrm{f}}$, Fatemeh Atyabi ${ }^{\mathrm{b}}$, Iraj Nabipour ${ }^{\mathrm{a}}$, Morteza Azhdarzadeh ${ }^{\mathrm{b}}$, Hossein Derakhshankhah ${ }^{\mathrm{g}}$, Alireza Lotfabadi ${ }^{g}$, Afshar Bargahi ${ }^{\mathrm{a}}$, Zahra Alekhamis ${ }^{\mathrm{b}}$, Afsaneh Aghaie ${ }^{\mathrm{h}}$, Ehsan Hashemi ${ }^{\mathrm{i}}$, Abbas Tafakhori ${ }^{j}$, Vajiheh Aghamollaii ${ }^{k}$, Marzie Maserat Mashhadi ${ }^{j}$, Sara Sheibani ${ }^{1}$, Hojatollah Vali, ${ }^{1, *}$ and Morteza Mahmoudi ${ }^{\mathrm{b}, *}$

a Persian Gulf Marine Biotechnology Research Center, The Persian Gulf Biomedical Sciences Research Institute, Bushehr University of Medical Sciences, Bushehr, Iran

${ }^{\mathrm{b}}$ Department of Nanotechnology and Nanotechnology Research Center, Faculty of Pharmacy, Tehran University of Medical Sciences, Tehran, Iran

${ }^{\mathrm{c}}$ Non-Communicable Diseases Research Center, Endocrinology and Metabolism Population Sciences Institute, Tehran University of Medical Sciences, Tehran, Iran

${ }^{\mathrm{d}}$ Department of Chemistry, Sharif University of Technology, Tehran, Iran

${ }^{\mathrm{e}}$ Department of New Materials and Biosystems, Max Planck Institute for Intelligent Systems, Stuttgart, Germany

${ }^{\mathrm{f}}$ Fachbereich Physik/Chemie, Philipps-Universität Marburg, Marburg, Germany

${ }^{\mathrm{g}}$ Department of Pharmaceutical Biomaterials and Medical Biomaterials Research Center,

Faculty of Pharmacy, Tehran University of Medical Sciences, Tehran, Iran

${ }^{\mathrm{h}}$ Blood Transfusion Research Center, High Institute for Research and Education in Transfusion Medicine,

Tehran, Iran

${ }^{\mathrm{i}}$ National Research Center for Transgenic Mouse, National Institute of Genetic Engineering and Biotechnology, Tehran, Iran

$\mathrm{j}$ Iranian Center of Neurological Research, Tehran University of Medical Sciences, Tehran, Iran

${ }^{\mathrm{k}}$ Roozbeh Hospital, Tehran University of Medical Sciences, Tehran, Iran

${ }^{1}$ Department of Anatomy and Cell Biology and Facility for Electron Microscopy Research,

McGill University, Montréal, QC, Canada

Accepted 9 June 2017

\begin{abstract}
It is well understood that patients with different diseases may have a variety of specific proteins (e.g., type, amount, and configuration) in their plasmas. When nanoparticles (NPs) are exposed to these plasmas, the resulting coronas may incorporate some of the disease-specific proteins. Using gold (Au) NPs with different surface properties and corona composition, we have developed a technology for the discrimination and detection of two neurodegenerative diseases, Alzheimer's disease (AD) and multiple sclerosis (MS). Applying a variety of techniques, including UV-visible spectra, colorimetric response analyses and liquid chromatography-tandem mass spectrometry, we found the corona-NP complexes, obtained from different human serums, had distinct protein composition, including some specific proteins that are known as AD and MS biomarkers. The colorimetric responses, analyzed by chemometrics and statistical methods, demonstrate
\end{abstract}

\footnotetext{
${ }^{*}$ Correspondence to: Hojatollah Vali, Department of Anatomy and Cell Biology and Facility for Electron Microscopy Research, McGill University, Montréal, QC, H3A 0C7, Canada. E-mail: hojatollah.vali@mcgill.ca and Morteza Mahmoudi, Department
}

of Nanotechnology and Nanotechnology Research Center, Faculty of Pharmacy, Tehran University of Medical Sciences, Tehran, 13169-43551, Iran. E-mail: mahmoudi-m@tums.ac.ir. 
promising capabilities of the technology to unambiguously identify and discriminate $\mathrm{AD}$ and MS. The developed colorimetric technology might enable a simple, inexpensive and rapid detection/discrimination of neurodegenerative diseases.

Keywords: Alzheimer's disease, colorimetric technology, disease-specific protein corona, gold nanoparticles, multiple sclerosis

\section{INTRODUCTION}

Exposure of nanoparticles (NPs) to physiological fluids results in their surfaces being covered by a biomolecular layer described as a "protein corona" [1-4]. The corona layer gives NPs a different identity compared to their original surface characteristics that will interact with biological systems in a specific way. The composition of the corona defines the bio-distribution, circulation half-life, toxicity and therapeutic efficacy of NPs [5-8]. Therefore, deep understanding of the protein corona composition is crucial to the predict the outcome of NPs in vivo [9].

Slight variations in the corona composition and structure can induce substantial differences in the biological fate of NPs [7, 10]. For instance, incorporation of apolipoprotein $\mathrm{E}$ into the corona composition can enable NPs to cross the blood-brain barrier (BBB) and reach brain tissue [11]. Recently, our group and others have demonstrated that changes in plasma composition, mediated by the type of disease, may be detected in the protein corona of exposed NPs [12-14]. This suggests patients with specific types of diseases have distinct corona composition termed "disease-specific protein corona" (DSPC) [12]. It has been proposed that the formation of the DSPC for different diseases is a consequence of the conformation, concentration, and function of the types of proteins in human plasma/serum. For example, patients with Alzheimer's disease (AD) experience higher levels of the serum amyloid protein, clusterin, Alpha-1-antichymotrypsin, complement factor $\mathrm{H}$ and $\alpha-1 / \beta-2-$ microglobulin with less Apo $C 3$, transthyretin, $A \beta 42: A \beta 40$ ratios and complement $\mathrm{C} 4$ compared to normal cases [15-20]. As another example, changing concentrations of anti-myelin antibodies, Epstein-Barr virus, interferon $\beta$-neutralizing antibodies, and tumor necrosis factor-related apoptosis-inducing ligand are serum biomarkers in multiple sclerosis (MS) patients [21-23]. In addition, the proteins involved in blood clotting, influence lipid transport pathways leading to a change in the composition of the serum of MS patients, especially in the early stages the disease [24]. These disease-specific serum changes can be used as potential biomarkers at the early stages, before appearance of any physical characteristic sign for MS disease. The $A \beta$ oligomer species ( $A \beta O s)$ are known as biomarkers that appear in initial phases of AD [25].

Small variations in the composition of plasma can make significant changes in the corona composition on the surfaces of the same NPs [26]. One could expect, therefore, that the DSPC may be used as a tool to discriminate and/or detect different types of diseases by investigating the plasma of patients with particular diseases. The development of diagnostic approaches for the identification and discrimination of diseases is one of the major challenges facing the scientific community. A major obstacle in disease detection is the clinical symptoms of some diseases, such as fibrillation-related disorders, cancer and MS, only appear at the late stages [27-30]. Currently, a patient's serum and cerebrospinal fluid (CSF) are used to discover new biomarkers (e.g., proteins, metabolites, and macromolecules). Disease-specific biomarkers (e.g., proteins and metabolites) are mainly identified using liquid chromatography-tandem mass spectrometry (LC-MS/MS). Madasamy's group identified several AD biomarkers using flow cytometerbased approaches [31-38]. The analysis of whole proteome and metabolome profiles of patient's serum/cerebrospinal fluid are, however, invasive, time consuming and expensive. In addition, analytical technics used for these analyses have moderate sensitivity.

Among the various type of sensors, the colorimetric technology is recognized as a rapid, economical, and concise approach for the detection of a wide range of compounds (e.g., biomolecules, environmental pollution compounds like NPs, toxic gases, heavy metals, and toxic industrial chemicals) [39-42]. Array-based detection works on the basis of cross-reactive interactions of different dyes with an analyte leading to the formation of specific colorimetric patterns. Although there is no specific interaction between a dye and analyte, the cross-reactive interactions of dye with sensor elements can provide a unique pattern for the desired analyte [43]. This approach is mimicked from the human mammalian olfactory system for the sense of smell [44]. In this paper, we describe the design and application of a colorimetric technology for the 
detection and discrimination of $\mathrm{AD}$ and MS. The system consists of four elements of spherical gold $\mathrm{Au}$ ) NPs of the same size but with different surface coatings including citrate, cysteine, cysteamine, and polyethyleneglycole. The Au NPs were incubated with $10 \%$ and $100 \%$ serums obtained from patients with different diseases. The system responses were measured by UV-visible spectra and analyzed by hierarchical cluster analysis (HCA), principal component analysis (PCA), and colorimetric different profile (CDP). Variation in the composition of the protein corona at the surfaces of Au NPs can change their surface plasmon resonance (SPR), which is the basis of sensing in the proposed technique. We have also probed the composition of the protein corona at the surfaces of various NPs obtained from the plasma of patients with different diseases using LC-MS/MS. Serum proteins have low binding affinity to NPs functionalized with zwitterions (Cystein) and therefore lower numbers of proteins, compared to other NPs, can be adsorbed to the surface of these NPs [45]. In this study, we identified the proteins present in the hard corona of citrate/cyteamine/polyethyleneglycole functionalized NPs.

\section{MATERIALS AND METHODS}

\section{Materials}

L-Cysteamine, sodium citrate, cysteine, thiosulfate sodium, sodium carbonate, glycine, Tris (hydroxymethyl) aminomethane, ammonium persulfate, hydrochloric acid, Sodium chloride, sodium hydrogen phosphate, potassium dihydrogen phosphate and Sodium hydroxide were purchased from Merck. Sodium borohydride, acetic acid, silver nitrate, methanol, ethanol, formaldehyde, sodium dodecyl sulfate, Tetramethylethylenediamine, 2mercaptoethanol, glycerol, polyethylene glycol, hydrogen tetrachloroaura cetyltrime-thylammonium bromide, L-ascorbic acid and other materials were purchased from Sigma.

\section{Au NPs synthesis and functionalization with citrate, cysteine, cysteamine and polyethylene glycol}

Citrate-stabilized Au NPs were prepared using Turkevich method with slight modification [46]. In order to prepare citrate-coated Au NPs, $5 \mathrm{ml}$ of sodium citrate $\left(38.8 \mathrm{mmol} \mathrm{L}^{-1}\right)$ was added to boiling solution of $50 \mathrm{ml}$ of $\mathrm{HAuCl}_{4}\left(1.0 \mathrm{mmol} \mathrm{L}^{-1}\right)$ and stirred for $30 \mathrm{~min}$ at $100^{\circ} \mathrm{C}$. In the next step, the synthesized Au NPs were cooled and functionalized with cysteine, cysteamine or polyethylene glycol. To this end, $\mathrm{Au}$ NPs were treated with each of cysteine $(8 \mu \mathrm{M})$, cysteamine $(2 \mu \mathrm{M})$ and thiolated polyethylene glycol $(10 \mu \mathrm{M})$ at room temperature, for 10 hours at $\mathrm{pH} 7.4$. After $10 \mathrm{~h}$ of incubation, the produced cysteine-Au, cysteamine-Au and thiolated polyethylene glycol-Au were collected and purified by triplicate centrifugation (at $13000 \mathrm{~g}$ for $10 \mathrm{~min}$ ) and washing.

\section{Characterization of synthesized Au NPs}

The synthesized Au NPs were characterized using UV-Visible spectrophotometer and transmission electron microscopy (TEM). All absorbance analyses were accomplished using a Lambda (PerkinElmer, USA) spectrophotometer at room temperature. The $\mathrm{Au}$ NP size and morphology were figure out by Phillips CM200 transmission electron microscope (TEM) equipped with an AMT 2_2 CCD camera at an accelerating voltage of $200 \mathrm{kV}$.

\section{Serum preparation}

Blood samples were collected from all volunteers after signing informed consent. The blood samples collected in clot tubes were allowed to clot at $4{ }^{\circ} \mathrm{C}$ for 30-60 minute and centrifuged following clot formation at $2500 \mathrm{~g}$ for $10 \mathrm{~min}$ at $4{ }^{\circ} \mathrm{C}$. The serum fractions obtained from same subjects (Patients with same disease) were pooled, divided into aliquots and frozen at $-20^{\circ} \mathrm{C}$. It should be noted that the sex and age (70-80) matched volunteers were selected for this study.

\section{Preparation of corona-coated citrate/cysteine/cysteamine/polyethylene glycol-Au NP complexes}

As slight temperature change affects the protein corona formation, the serums (10\% and 100\%) from $\mathrm{AD}, \mathrm{MS}$ and normal cases and functionalized $\mathrm{Au}$ NPs were maintained at $37^{\circ} \mathrm{C}$ for $10 \mathrm{~min}$ [47]. In the next step, the functionalized Au NPs were incubated with the serums $(10 \%$ and $100 \%)$ at a final concentration of $100 \mu \mathrm{g} \mathrm{m}{ }^{-1}$ at $37^{\circ} \mathrm{C}$ for $60 \mathrm{~min}$ (Total volume was $500 \mu \mathrm{l}$ ). Immediately after $60 \mathrm{~min}$, the solutions were centrifuged for $20 \mathrm{~min}$ at $14000 \mathrm{~g}$ at $15^{\circ} \mathrm{C}$ to separate the corona-coated NP complexes. Then, the supernatant was gently removed and NP-protein pellet was resuspended in $\mathrm{PBS}\left(15^{\circ} \mathrm{C}\right)$ 
and centrifuged for $15 \mathrm{~min}$ at $14000 \mathrm{~g}$ at $15^{\circ} \mathrm{C}$. The washing step was repeated for three times. The triplicate washing lead to detachment of loosely bound proteins. Finally, the resulted hard corona-coated $\mathrm{Au}$ NPs were resuspended in $250 \mu \mathrm{l}$ of PBS (1\%) and used for further analyses.

\section{Dynamic light scattering (DLS) and zeta potential}

Size distribution of corona-coated citrate/cysteine/ cysteamine/polyethylene glycol-Au complexes were measured using Malvern PCS-4700 instrument equipped with a 256-channel correlator. The surface charges of these complexes were measured by Malvern Zetasizer 3000 HSA. All of these analyses were performed at $25^{\circ} \mathrm{C}$ and repeated for three times.
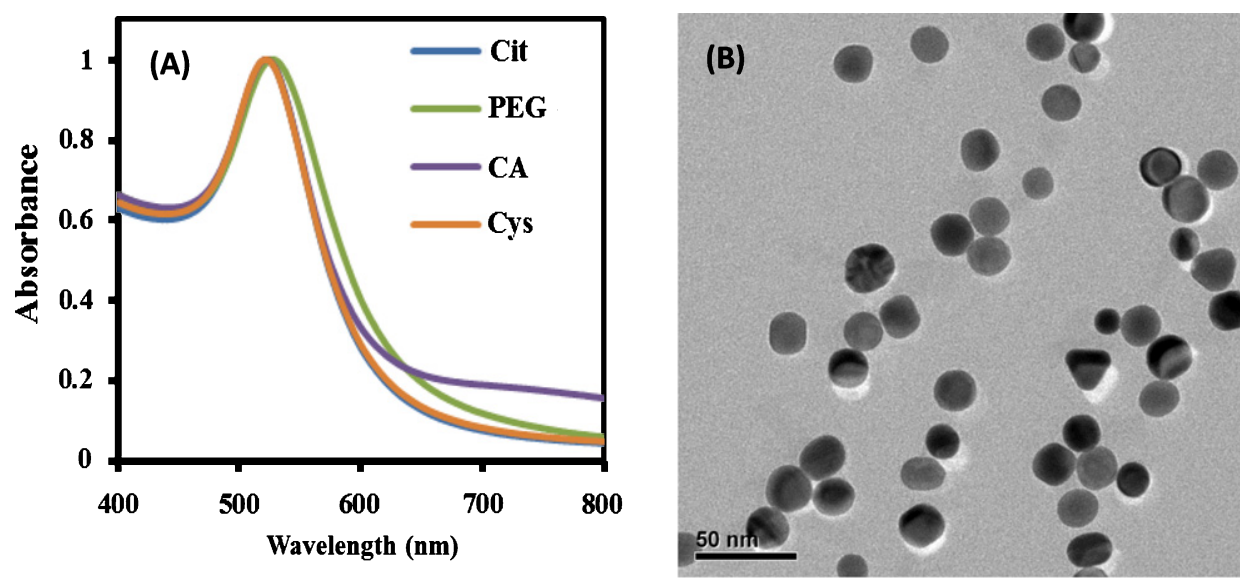

(C)

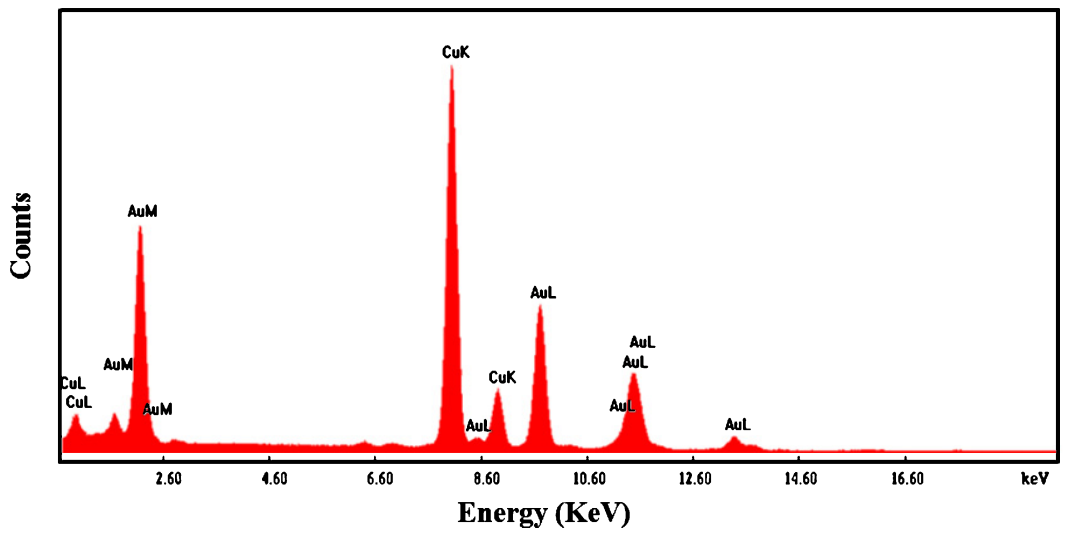

Fig. 1. UV-vis spectra of Au NPs functionalized with citrate, cysteine, cysteamine and polyethyleneglycole (A). Transmission electron microscope (TEM) image of prepared Au NPs (B). Energy dispersive spectroscopy (EDS) analysis of prepared Au NPs (C). 


\section{RESULTS AND DISCUSSION}

\section{NP synthesis and characterization}

The presence of a specific peak at $520 \mathrm{~nm}$ confirmed the presence of stable Au NPs in the prepared solutions (Fig. 1A). The UV-visible spectra of citrate/cysteine/cysteamine/polyethylene glycol-coated Au NPs demonstrated no considerable shift in the SPR peak position. On the basis of this result, it is evident the Au NPs have not aggregated in the prepared solutions. Owing to their monodispersed state, the NPs are promising candidates for investigating changes in SPR caused by disease-specific protein coronas (DSPC). Images from transmission electron microscopy (TEM) show sphere-shaped $\mathrm{Au}$ NPs $(20 \mathrm{~nm}$ ) with a narrow size distribution (Fig. 1B). Energy dispersive X-ray spectroscopy (EDS) analysis confirmed the presence of pure Au NPs in solution (Fig. 1C).

\section{$U V$-visible spectra of DSPC-Au NP complexes} from different patients

The citrate/cysteine/cysteamine/polyethylene glycol-coated Au NPs were incubated with $10 \%$ and $100 \%$ serums from various patients and the final DSPC-Au NP complexes measured by UV-visible spectrometry at a wavelength of $400-780 \mathrm{~nm}$. Although the SPRs of all corona-coated Au NP complexes obtained from $10 \%$ serums showed no significant shift in peak position, the SPR intensities of some complexes were different from each other (Fig. 2A-D). For example, all corona-coated Au NPs complexes obtained from serums of healthy individuals showed the least SPR intensity except for corona-coated citrate-NPs, which showed the highest intensity (Fig. 2A-D). The SPR intensities of complexes obtained from serums of $\mathrm{AD}$ and MS patients were similar (Figs. 2B,D). However, the DSPC-Au NP complexes obtained from $10 \%$
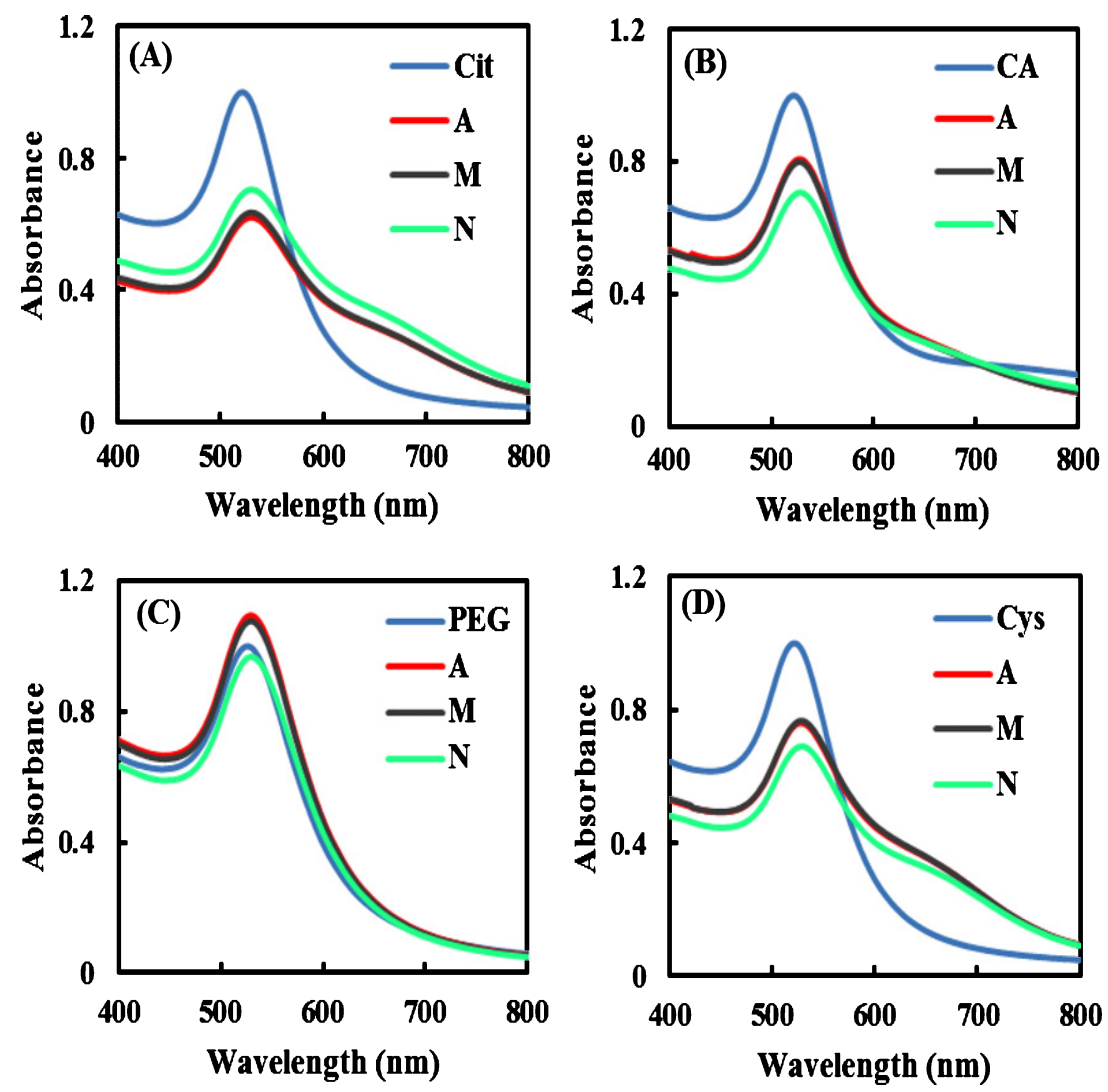

Fig. 2. UV-vis spectra of corona-coated citrate-Au NPs (A), corona-coated cysteamine-Au NPs (B), corona-coated polyethyleneglycole$\mathrm{Au}$ NPs (C) and corona-coated cysteine-Au NPs (D) obtained following incubation with $10 \%$ serums of normal, AD and MS cases. 
serums can be used to discriminate between healthy individuals and $\mathrm{AD} / \mathrm{MS}$ patients. It should be noted that these complexes do not discriminate between different diseases. For DSPC-NP complexes from $100 \%$ serums, changes in SPR intensity, and in some cases, peak broadening, were observed (Fig. 3A-D). According to the spectral responses recorded for corona-coated citrate-Au NP complexes, distinctive spectra are characteristic for $\mathrm{AD}$ and MS (Fig. 3A). As a result of DSPC formation, distinct spectral response permits the facile and rapid detection and discrimination of AD and MS. The different spectral patterns suggest the coronas have a different protein composition.

\section{Analysis of the array responses by hierarchical} cluster analysis, principal component analysis and color difference profile

In the method of HCA, different diseases are clustered on the basis of their spatial distances and the results plotted on a dendrogram. The HCA dendrogram represents a view of data clustering in which the cluster distance is known as an index of likeness level of samples [49]. For $10 \%$ serum, the HCA dendrogram shows $\mathrm{AD}$ and MS have short or insignificant cluster distances while both diseases have long cluster distances to healthy individuals (Fig. 4A). On the basis of the HCA dendrogram for $100 \%$ serum, all AD and MS patients and healthy individuals have long cluster distances from each other (Fig. 4B). The array responses were also analyzed using principal component analysis (PCA) to quantitatively evaluate sample dispersion and determine similarity in the diseases. In the PCA plot, the level of class distribution and separation is known as index of similarity level [50]. In the score plots generated for $10 \%$ serum, the horizontal PC1 axis and the vertical PC2 axis captured 96.1\% and $3.2 \%$ of the variance, respectively (Fig. 5A). As shown in Fig. 5A, the healthy samples can just be discriminated from the disease cases. Indeed, the degree of class separation among different diseases were insignificant, and hence, they cannot be discriminated from each other. In the score plot designed for $100 \%$ serum, the horizontal PC1 axis and the vertical PC2 axis captured $93.2 \%$ and $5.4 \%$ of the variance,
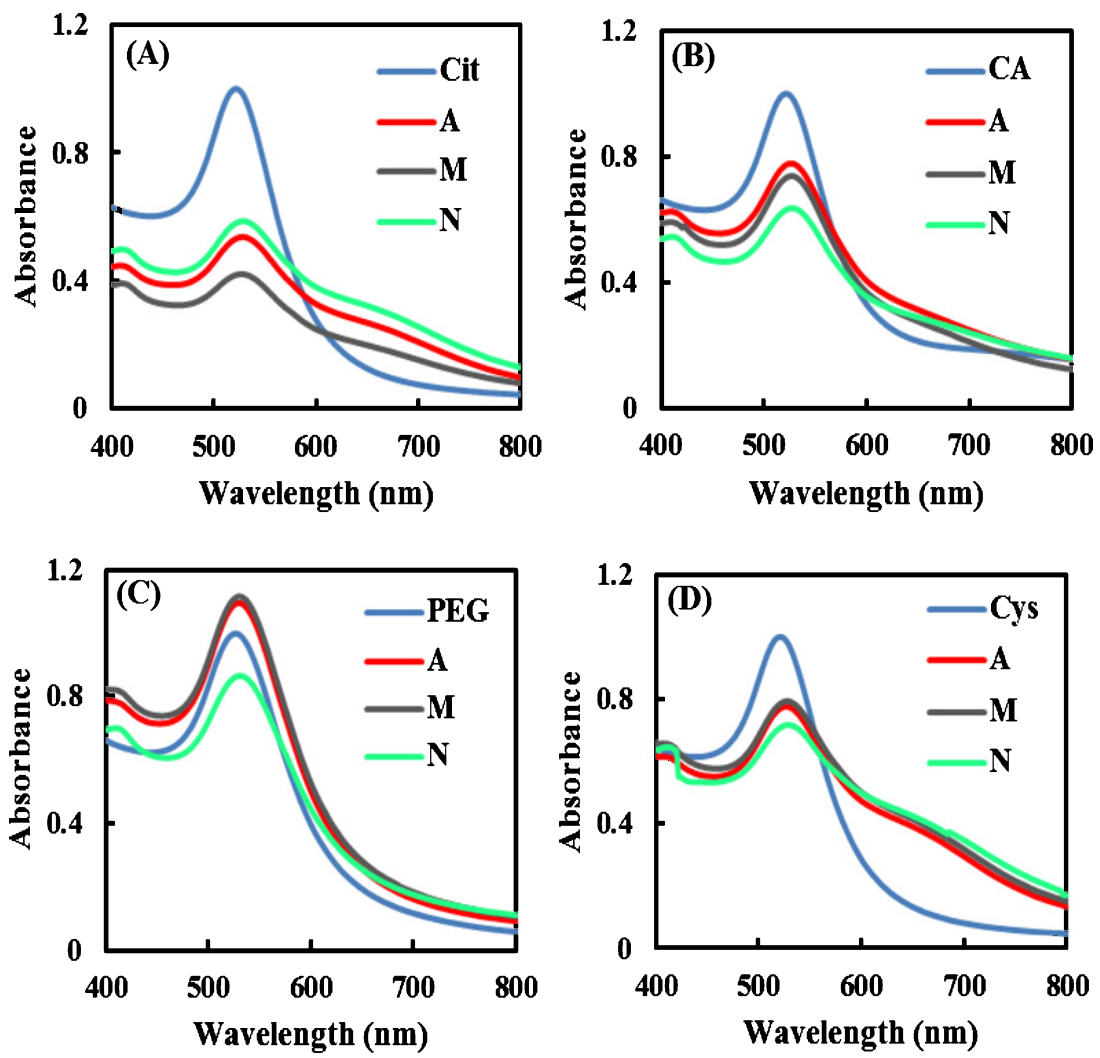

Fig. 3. UV-vis spectra of corona-coated citrate-Au NPs (A), corona-coated cysteamine-Au NPs (B), corona-coated polyethyleneglycole-Au NPs (C) and corona-coated cysteine-Au NPs (D) obtained following incubation with $100 \%$ serums of normal, AD and MS cases. 


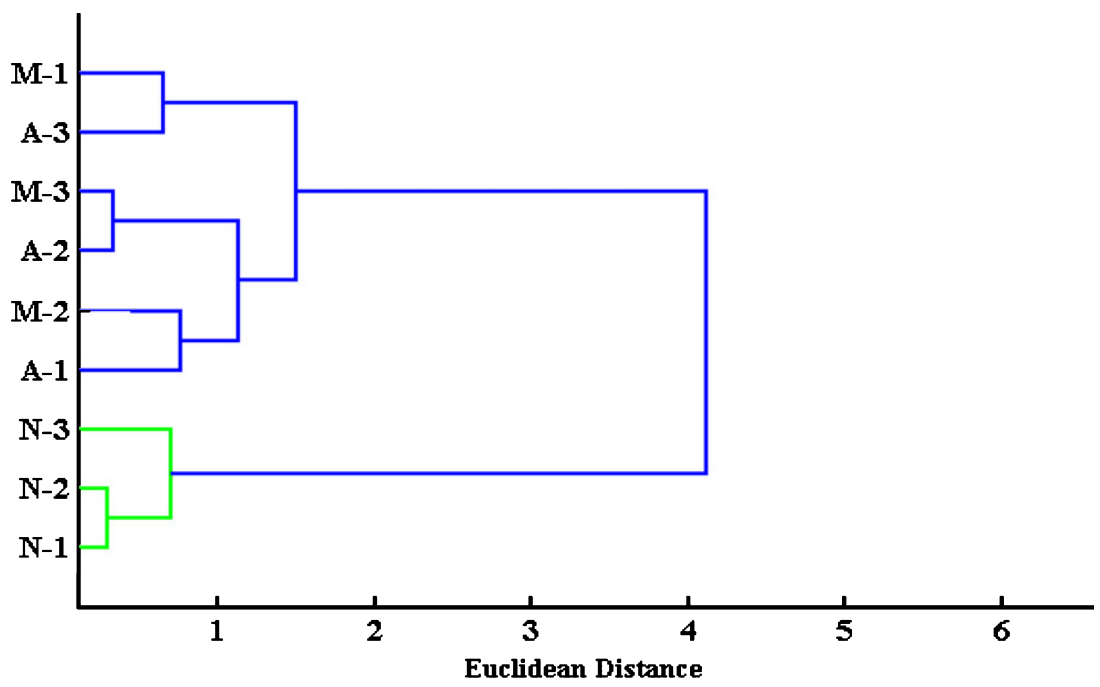

(A)

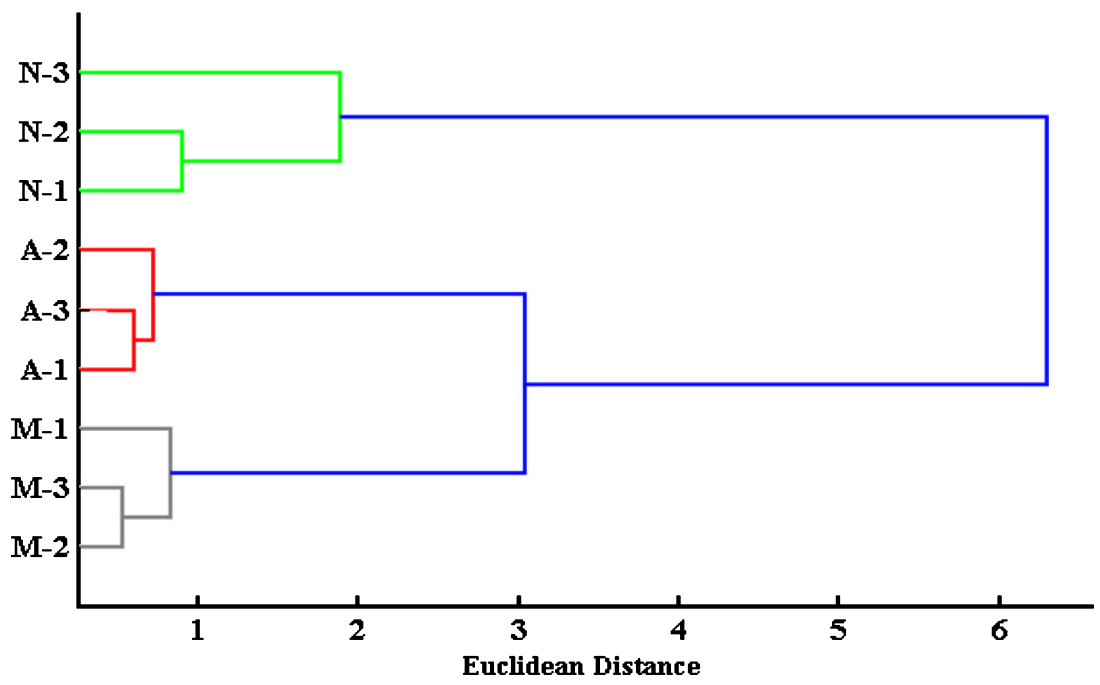

(B)

Fig. 4. HCA dendrogram showing the Euclidean distance among different clusters for corona profiles of $10 \%$ serum (A) and $100 \%$ serum (B).

respectively (Fig. 5B). For 100\% serum, all cases can be discriminated from each other. The degree of class separation among $\mathrm{AD}, \mathrm{MS}$ and healthy individuals were significant, and hence, they can be differentiated (Fig. 5B). These findings can be explained by disease-specific changes in the serum mediated by the disease. Because the colorimetric technology developed in this study differentiate diseases on the basis of the spectral variations driven by DSPCs, they can specifically discriminate patients who have specific protein coronas. In order to differentiate various diseases, even at a glance, CDP was generated by taking the value of the $\Delta \mathrm{A}$ of three selected visible wave- lengths (i.e., 520, 570 and $630 \mathrm{~nm}$ ). CDP provided clear color changes that can be distinguished at a glance. On the basis of the CDP for $10 \%$ serum, it is possible to differentiate the healthy case from disease (Fig. 6A). The color changes detected for normal cases may be related to their different SPR intensities. According to the CDP for $100 \%$ serum, all cases (AD, MS and healthy) can be distinguished from each other (Fig. 6B). The analysis of the collective array responses by HCA, PCA and CDP suggest DSPC formation can be used to develop colorimetric sensor arrays that specifically discriminate and detect different diseases. 


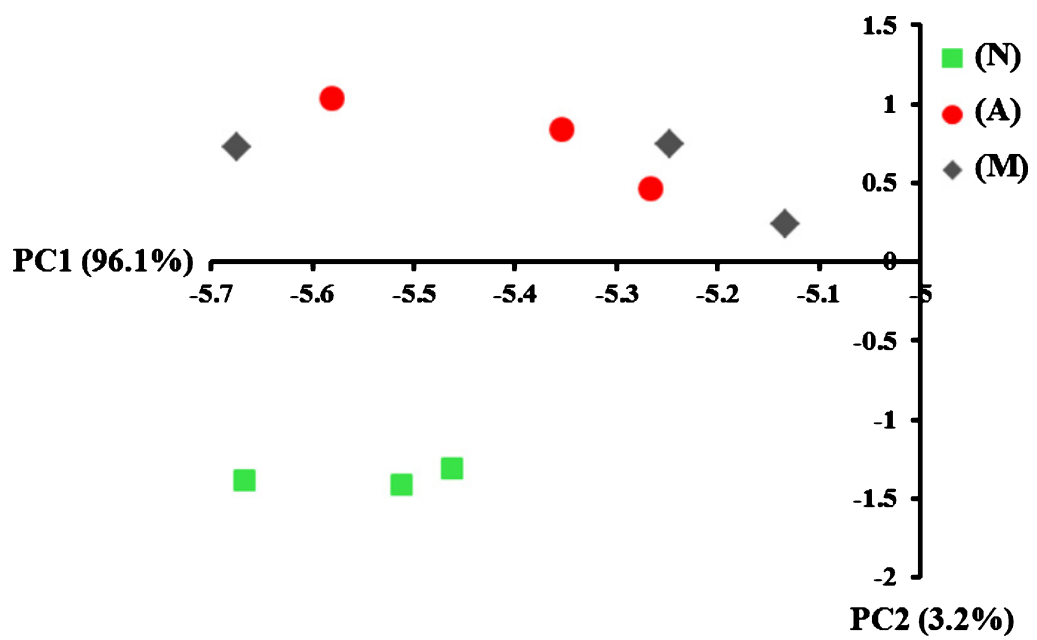

(A)

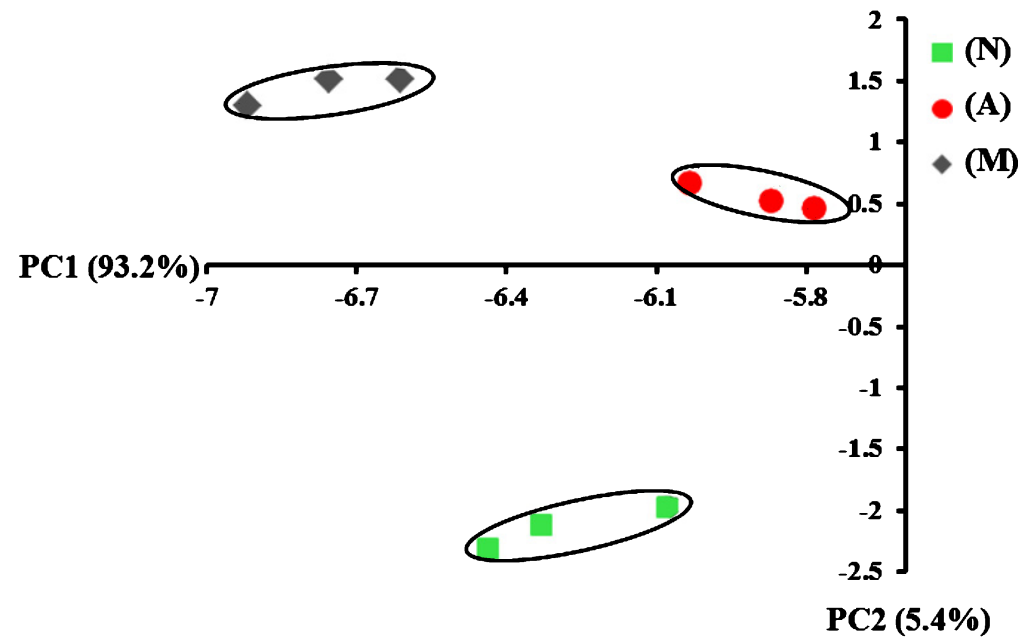

(B)

Fig. 5. Two-dimensional score plot showing degree of class separation among normal, AD and MS cases for 10\% serum (A) and $100 \%$ serum (B).

\section{Size and charge of corona-coated NP complexes}

Considering that the size and surface charge of corona-coated NPs are contingent upon the type and affinity of the adsorbed proteins [12], the same NPs will have different properties after exposure to the serum of different patients. Analysis of the size distribution and zeta potential value of corona-coated $\mathrm{Au}$ NPs obtained from serums of various patients confirmed this behavior (Tables 1A-D). These results are consistent with previous studies showing personalized protein corona from various patients have distinct size and surface charge [12,26].
Effects of serum composition on protein corona formation in patients with different diseases

The identified proteins were classified based on their association within different coronas. We found that many proteins (conserved proteins) associated within all coronas (Supplementary Tables 1-6), while some specific proteins exclusively appeared and/or disappeared in hard coronas obtained from particular type of serums (Tables 2-7). In addition, the majority of conserved proteins differently associated within various coronas. These results suggest coronas formed on the surfaces of NPs exposed to serum of 


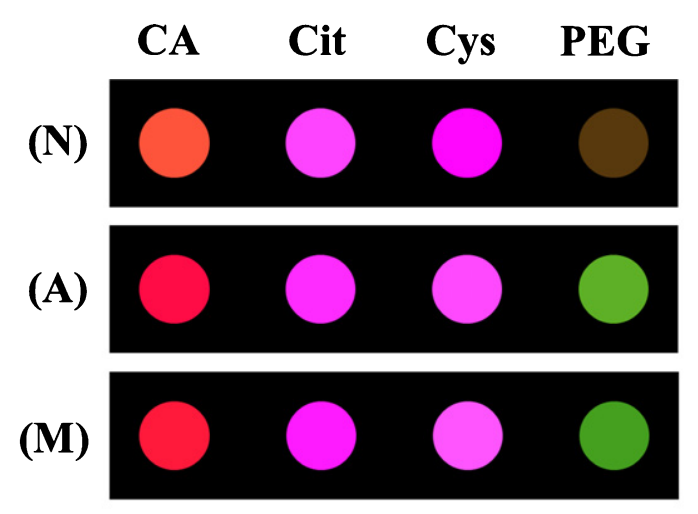

(A)

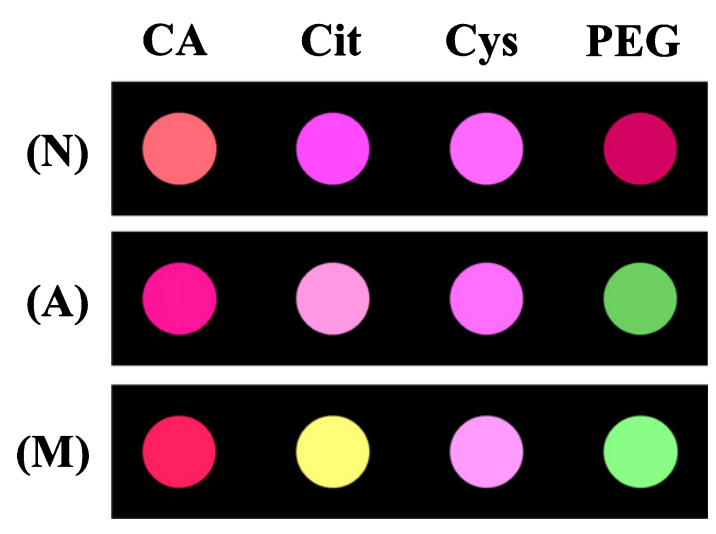

(B)

Fig. 6. Color difference profile for normal, AD and MS cases for $10 \%$ serum (A) and $100 \%$ serum (B).

patients with various diseases are different in terms of the composition and concentration (Tables 2-7, Supplementary Tables 1-6). The conserved proteins (e.g., serum albumin, immunoglobulin, apolipoproteins, and complement factors) showed more association within the protein corona compared to specific proteins (Supplementary Tables 1-6). For citrate-coated NPs, the coronas obtained from $10 \%$ serums (diluted in PBS) showed more similarity in their protein pattern compared to those obtained from $100 \%$ serums (Supplementary Table 1A,B). Similar results were also observed for PEG-coated NPs (Supplementary Table 3A,B). Interestingly, some proteins were specifically detected in the coronas of both $\mathrm{AD}$ and MS. These proteins may help to distinguish patients from normal cases. In the case of cysteamine-coated NPs, apolipoproteins and platelet basic protein seem to be the main component of the hard coronas of both AD and MS (Supplementary Table 2A,B).
Specific proteins identified in the coronas obtained from the serum of patients with a particular disease can be considered as biomarkers predicting disease prevalence and risk (Tables 2-7). Interestingly, some serum proteins that are known as $\mathrm{AD}$ and/or MS biomarkers were specifically detected in hard coronas obtained from serums of $\mathrm{AD}$ and/or MS diseases. For example, Insulin-like growth factor-binding protein 3, gelsolin, antithrombin, clusterin, Thrombospondin-1 and platelet-basic, which are known as MS biomarkers [51-53], were detected in hard coronas obtained from serums of patients with MS diseases. In addition, AD-specific biomarkers such as Serum amyloid $\mathrm{P}$, complement factor $\mathrm{H}$, Alpha-2-macroglobulin, transthyretin, clusterin, tau-tubulin kinase, Alpha-1-antichymotrypsin, Apolipoprotein B100 and gelsolin were identified in coronas obtained from serums of $\mathrm{AD}$ patients [48, 54-57].

Insulin-like growth factor-binding protein 3, gelsolin, antithrombin and clusterin, as MS biomarkers, were only recognized in the corona of cysteamineNP obtained from 10\% serum of MS patients (Table 5). The MS-specific biomarkers such as Thrombospondin-1 and platelet-basic protein were identified in the corona of citrate-NPs obtained from $100 \%$ serum of MS patients (Table 2). Serum amyloid $\mathrm{P}$ and complement factor $\mathrm{H}$, as $\mathrm{AD}$ biomarkers, were recognized in the corona of cysteamineNPs obtained after incubation with $100 \%$ serum of AD patients (Table 4). Alpha-2-macroglobulin, transthyretin, clusterin, and tau-tubulin kinase, as $\mathrm{AD}$ biomarkers, were only detected in the corona of citrate-NPs obtained from $10 \%$ serum of patients with AD (Table 3). Apolipoprotein B100 and gelsolin, as AD biomarkers, were specifically identified in the coronas of PEG-NPs obtained from $100 \%$ and $10 \%$ serums of AD patients respectively (Tables 6 and 7). Alpha-1-antichymotrypsin, as AD biomarker, was only identified in the corona of citrate-NPs obtained from $100 \%$ serum of AD patients (Table 2). This hard corona complex also had the least amount of apolipoprotein E compared to those obtained from other serums. These results are in agreement with previous studies showing a decrease in the concentration of serum apolipoprotein $\mathrm{E}$ in patients with $\mathrm{AD}$ [58].

The results of this study are in line with other studies showing that each patient may have a diseasespecific protein corona [59, 60]. Every change in serum protein concentration and structure may affect the affinity of proteins toward the NPs and protein 
Table 1

DLS and zeta potential values of corona-coated citrate-Au NPs (A), corona-coated cysteamine-Au NPs (B), corona-coated polyethyleneglycole-Au NPs (C) and corona-coated cysteine-Au NPs (D) obtained from $10 \%$ and $100 \%$ serums of normal, AD and MS cases

\begin{tabular}{lcccc}
\hline A & & & & \\
\hline Protein corona-coated citrate-Au & DLS serum & Zeta serum & DLS serum & Zeta serum \\
NPs obtained from normal/patient & $10 \%(\mathrm{~nm})$ & $10 \%(\mathrm{mV})$ & $100 \%(\mathrm{~nm})$ & $100 \%(\mathrm{mV})$ \\
\hline Normal & $53 \pm 09$ & -9 & $41 \pm 07$ & -9 \\
Alzheimer's disease & $67 \pm 05$ & -9 & $83 \pm 22$ & -11 \\
Multi sclerosis & $51 \pm 04$ & -8 & $59 \pm 10$ & -6 \\
\hline B & & & & \\
\hline Protein corona-coated cysteamine- & DLS serum & Zeta serum & DLS serum & Zeta serum \\
Au NPs obtained from normal/patient & $10 \%(\mathrm{~nm})$ & $10 \%(\mathrm{mV})$ & $100 \%(\mathrm{~nm})$ & $100 \%(\mathrm{mV})$ \\
\hline Normal & $37 \pm 09$ & -9 & $65 \pm 11$ & -10 \\
Alzheimer's disease & $62 \pm 07$ & -8 & $43 \pm 10$ & -7 \\
Multi sclerosis & $59 \pm 05$ & -4 & $85 \pm 08$ & -6 \\
\hline C & & & & Zeta serum \\
\hline Protein corona-coated PEG-Au & DLS serum & Zeta serum & DLS serum & $100 \%(\mathrm{mV})$ \\
NPs obtained from normal/patient & $10 \%(\mathrm{~nm})$ & $10 \%(\mathrm{mV})$ & $100 \%(\mathrm{~nm})$ & 100 \\
\hline Normal & $88 \pm 15$ & -8 & $127 \pm 24$ & -8 \\
Alzheimer's disease & $56 \pm 04$ & -3 & $164 \pm 21$ & -5 \\
Multi sclerosis & $81 \pm 08$ & -7 & $68 \pm 15$ & -6 \\
\hline D & & & & \\
\hline Protein corona-coated cysteine- & DLS serum & Zeta serum & DLS serum & Zeta serum \\
Au NPs obtained from normal/patient & $10 \%(\mathrm{~nm})$ & $10 \%(\mathrm{mV})$ & $100 \%(\mathrm{~nm})$ & $100 \%(\mathrm{mV})$ \\
\hline Normal & $59 \pm 13$ & -3 & $77 \pm 14$ & -6 \\
Alzheimer's disease & $47 \pm 10$ & -5 & $60 \pm 12$ & -4 \\
Multi sclerosis & $69 \pm 16$ & -7 & $87 \pm 08$ & -10 \\
\hline
\end{tabular}

Table 2

Proteins only detected in the coronas of citrate-NPs obtained from $100 \%$ serums of AD and MS patients

\begin{tabular}{|c|c|c|c|}
\hline Protein identity & $\mathrm{NSpC}$ & Protein identity & $\mathrm{NSpC}$ \\
\hline $\begin{array}{l}\text { (Corona coated Citrate-NPs obtained after } \\
\text { incubation with } 100 \% \text { serum of AD cases) }\end{array}$ & & $\begin{array}{l}\text { (Corona coated Citrate-NPs obtained after } \\
\text { incubation with } 100 \% \text { serum of MS cases) }\end{array}$ & \\
\hline Apolipoprotein B-100 & 0.961888 & Ketohexokinase & 0.632403 \\
\hline Protein APOC4-APOC2 & 2.603969 & Histone-lysine N-methyltransferase & 0.061802 \\
\hline Ig heavy chain V-I region 5 & 2.04232 & $\begin{array}{l}\text { Disintegrin and metalloproteinase domain- } \\
\text { containing protein } 12\end{array}$ & 0.206624 \\
\hline Protein SAA2-SAA4 & 2.235544 & ATP-binding cassette sub-family $\mathrm{C}$ member 11 & 0.133295 \\
\hline Alpha-1-antichymotrypsin & 0.547795 & Complement $\mathrm{C} 1 \mathrm{q}$ subcomponent subunit $\mathrm{C}$ & 0.798011 \\
\hline Trinucleotide repeat-containing gene $6 \mathrm{~B}$ protein & 0.134548 & Sickle tail protein homolog & 0.096056 \\
\hline Tetratricopeptide repeat protein 6 & 0.1206 & Thrombospondin-1 & 0.158966 \\
\hline Exonuclease $3^{\prime}-5$ ' domain-containing protein 2 & 0.371033 & Ig heavy chain V-III region POM & 1.587822 \\
\hline Ras-related protein Rab-28 & 1.050776 & Protein IGKV1-33 & 1.736743 \\
\hline Mitogen-activated protein kinase kinase kinase 4 & 0.143672 & Myosin-9 & 0.090791 \\
\hline Supervillin & 0.105361 & Complement factor $\mathrm{H}$ & 0.147868 \\
\hline RING finger protein 225 & 0.750325 & Ig kappa chain V-II region RPMI 6410 & 1.398541 \\
\hline Nuclear pore complex protein Nup205 & 0.114527 & Ig mu chain $\mathrm{C}$ region & 2.817381 \\
\hline G-rich sequence factor 1 & 0.491337 & Ig kappa chain V-IV region Len & 1.627166 \\
\hline \multirow[t]{10}{*}{ Aryl hydrocarbon receptor repressor } & 0.342271 & Ig heavy chain V-III region BRO & 1.555028 \\
\hline & & Immunoglobulin lambda-like polypeptide 5 & 1.776829 \\
\hline & & Apolipoprotein A-IV & 1.359086 \\
\hline & & Alpha-1-acid glycoprotein 1 & 0.874765 \\
\hline & & Antithrombin-III & 0.390998 \\
\hline & & Ig lambda chain V-IV region Hil & 1.785783 \\
\hline & & Immunoglobulin $\mathrm{J}$ chain & 1.136416 \\
\hline & & Ig kappa chain V-III region SIE & 1.746631 \\
\hline & & Hemoglobin subunit beta & 2.571223 \\
\hline & & Platelet basic protein & 2.960657 \\
\hline
\end{tabular}


Table 3

Proteins only detected in the coronas of citrate-NPs obtained from $10 \%$ serums of AD and MS patients

\begin{tabular}{llll}
\hline Protein identity & NSpC & Protein identity \\
(Corona coated Citrate-NPs obtained after & & $\begin{array}{l}\text { (Corona coated Citrate-NPs obtained after } \\
\text { incubation with 10\% serum of MS cases) }\end{array}$ \\
incubation with 10\% serum of AD cases) & & Ig kappa chain V-III region SIE & Apolipoprotein A-IV \\
Clusterin & 0.44663 & Apolipoprotein B-100 & 0.554525 \\
Protein FAM65C & 0.22268 & 1.16944 & Ig heavy chain V-III region POM \\
Protein APOC4-APOC2 & 0.47746 & VPS10 domain-containing receptor SorCS2 \\
Haptoglobin & 1.83441 & Immunoglobulin lambda-like polypeptide 5 \\
Ig heavy chain V-I region 5 & 1.97979 & \\
Protein IGKV1-33 & 0.50625 & Apolipoprotein L1 \\
Pigment epithelium-derived factor & 0.52293 & \\
Alpha-2,8-sialyltransferase 8F & 0.34651 & \\
Integrator complex subunit 11 & 1.1638 & \\
Transthyretin & 0.45558 & \\
Metaxin 1, isoform CRA_b & 0.12849 & \\
Tau-tubulin kinase & 1.83441 & \\
Piezo-type mechanosensitive ion channel component 1 & 0.14358 & \\
Alpha-2-macroglobulin & 1.59426 & \\
Ig kappa chain V-II region & 0.62265 & \\
Ig alpha-1 chain C region & 0.59489 & \\
Alpha-2-HS-glycoprotein & 0.69954 & \\
C4b-binding protein alpha chain & & \\
\hline
\end{tabular}

Table 4

Proteins only detected in the coronas of cysteamine-NPs obtained from $100 \%$ serums of AD and MS patients

\begin{tabular}{|c|c|c|c|}
\hline $\begin{array}{l}\text { Protein identity } \\
\text { (Corona coated cysteamine-NPs obtained after } \\
\text { incubation with } 100 \% \text { serum of AD cases) }\end{array}$ & $\mathrm{NSpC}$ & $\begin{array}{l}\text { Protein identity } \\
\text { (Corona coated cysteamine-NPs obtained after } \\
\text { incubation with } 100 \% \text { serum of MS cases) }\end{array}$ & $\mathrm{NSpC}$ \\
\hline Coagulation factor XII & 0.5714 & Protein FAM65C & 1.81545 \\
\hline Antithrombin-III & 2.94556 & Elongation factor Tu, mitochondrial & 3.85839 \\
\hline Fibronectin & 0.58998 & Neurogenic locus notch homolog protein 4 & 0.91192 \\
\hline Complement factor H-related protein 1 & 2.05769 & Kalirin & 0.561772 \\
\hline Apolipoprotein A-IV & 0.85322 & Phosphatidylinositol 4-kinase alpha & 0.807126 \\
\hline Ig lambda-2 chain $\mathrm{C}$ regions (Fragment) & 6.82738 & $\begin{array}{l}\text { Dual 3',5'-cyclic-AMP and -GMP } \\
\text { phosphodiesterase 11A }\end{array}$ & 1.824797 \\
\hline Ig kappa chain $\mathrm{C}$ region & 1.48438 & Niban-like protein 1 & 2.271855 \\
\hline Plasma kallikrein (Fragment) & 0.50384 & Dynein heavy chain 8 , axonemal & 0.354907 \\
\hline ITIH4 protein & 0.37288 & & \\
\hline Serum amyloid P-component & 1.52581 & & \\
\hline Partitioning defective 3 homolog B & 0.29235 & & \\
\hline $\mathrm{N}$-terminal EF-hand calcium-binding protein 3 & 1.66386 & & \\
\hline $\begin{array}{l}\text { Pleckstrin homology domain-containing family } \mathrm{O} \\
\text { member } 1\end{array}$ & 0.83774 & & \\
\hline Paralemmin-1 & 0.9206 & & \\
\hline Protein Hook homolog 1 & 0.45761 & & \\
\hline SURP and G-patch domain-containing protein 2 & 0.3187 & & \\
\hline Transcription factor SOX-18 & 0.94727 & & \\
\hline T-complex protein 1 subunit zeta & 0.66757 & & \\
\hline Lysine-specific demethylase $5 \mathrm{~A}$ & 0.19789 & & \\
\hline Prothrombin & 0.55308 & & \\
\hline Thrombospondin-1 & 0.29939 & & \\
\hline $\begin{array}{l}\text { Transient receptor potential cation channel subfamily } \\
\text { V member } 3\end{array}$ & 0.42738 & & \\
\hline Nesprin-1 & 0.03831 & & \\
\hline ETS translocation variant 3 & 0.67955 & & \\
\hline T-cell immunoreceptor with Ig and ITIM domains & 1.14179 & & \\
\hline NKG2D ligand 4 & 1.286 & & \\
\hline
\end{tabular}


Table 5

Proteins only detected in the coronas of cysteamine-NPs obtained from $10 \%$ serums of AD and MS patients

\begin{tabular}{|c|c|c|c|}
\hline Protein identity & $\mathrm{NSpC}$ & Protein identity & $\mathrm{NSpC}$ \\
\hline $\begin{array}{l}\text { (Corona coated cysteamine-NPs obtained after } \\
\text { incubation with } 10 \% \text { serum of AD cases) }\end{array}$ & & $\begin{array}{l}\text { (Corona coated cysteamine-NPs obtained after } \\
\text { incubation with } 10 \% \text { serum of MS cases) }\end{array}$ & \\
\hline Ig kappa chain V-III region WOL & 7.628765 & Pre-mRNA-splicing factor CWC25 homolog & 0.232449 \\
\hline Gelsolin & 0.522827 & Tyrosine-protein kinase SgK223 & 0.077132 \\
\hline Ig kappa chain V-III region HAH & 6.367611 & $\begin{array}{l}\text { Glutaredoxin domain-containing cysteine-rich } \\
\text { protein } 2\end{array}$ & 0.408032 \\
\hline Coagulation factor XII & 0.330468 & Probable C-mannosyltransferase DPY19L3 & 0.13872 \\
\hline Proline-rich protein 11 & 0.558875 & PWWP domain-containing protein MUM1 & 0.142776 \\
\hline Ig heavy chain V-III region BRO & 1.69379 & Rhodopsin kinase & 0.181672 \\
\hline Pigment epithelium-derived factor & 0.483731 & Sterile alpha motif domain-containing protein 11 & 0.15857 \\
\hline F-box/LRR-repeat protein 18 & 0.253597 & $\mathrm{ABI}$ gene family member 3 & 0.295645 \\
\hline p53-induced death domain-containing protein 1 & 0.224674 & Solute carrier family 15 member 2 & 0.141116 \\
\hline Fibronectin & 0.085303 & Synaptopodin & 0.116028 \\
\hline Aldehyde dehydrogenase, mitochondrial & 0.39734 & Ig kappa chain V-II region RPMI 6410 & 0.784746 \\
\hline Puromycin-sensitive aminopeptidase & 0.21692 & Cytochrome c & 0.98232 \\
\hline Cell division cycle 5 -like protein & 0.242841 & Protein IGLV3-27 (Fragment) & 0.948706 \\
\hline Group XIIA secretory phospholipase A2 & 1.063436 & Immunoglobulin J chain & 0.637663 \\
\hline & & Ig kappa chain V-I region Kue & 0.951681 \\
\hline & & Protein IGLV3-19 (Fragment) & 0.958323 \\
\hline & & Complement $\mathrm{C} 1 \mathrm{r}$ subcomponent & 0.140932 \\
\hline & & Clusterin & 0.219847 \\
\hline & & Protein TRAV34 (Fragment) & 0.925858 \\
\hline & & $\begin{array}{l}\text { Microtubule-associated serine/threonine-protein } \\
\text { kinase } 4 \text { (Fragment) }\end{array}$ & 1.540459 \\
\hline & & Conserved oligomeric Golgi complex subunit 5 & 0.124437 \\
\hline & & Ig lambda chain V-I region WAH & 0.984248 \\
\hline & & Cytoplasmic dynein 2 heavy chain 1 & 0.023427 \\
\hline & & Ig kappa chain V-III region B6 & 0.991866 \\
\hline & & Pre-mRNA-processing factor 17 & 0.189719 \\
\hline & & Insulin-like growth factor-binding protein 3 & 0.364359 \\
\hline & & Apolipoprotein L1 & 0.262439 \\
\hline & & Protein IGLV3-21 (Fragment) & 0.927273 \\
\hline & & Ig gamma- 3 chain $\mathrm{C}$ region & 1.615353 \\
\hline & & Protein IGKV1-8 & 1.734001 \\
\hline & & Protein IGKV1-12 & 1.725268 \\
\hline & & Alpha-1-antitrypsin & 1.729556 \\
\hline & & Complement factor $\mathrm{H}$-related protein 1 & 1.226112 \\
\hline & & Alpha-2-macroglobulin & 0.353378 \\
\hline & & Complement C1q subcomponent subunit B & 1.295696 \\
\hline & & Serotransferrin & 0.449272 \\
\hline & & Protein IGHV3OR16-12 (Fragment) & 0.896426 \\
\hline & & Ig heavy chain V-I region V35 & 0.887186 \\
\hline & & Haptoglobin & 0.510588 \\
\hline & & Alpha-2-HS-glycoprotein 1 & 0.585646 \\
\hline & & Antithrombin-III & 0.438792 \\
\hline & & Ig heavy chain V-I region 5 (Fragment) & 1.805906 \\
\hline & & Ig lambda chain V-I region BL2 & 0.850798 \\
\hline & & Alpha-1-acid glycoprotein 1 & 0.981693 \\
\hline & & Protein IGHV3-15 (Fragment) & 0.892887 \\
\hline & & Ig kappa chain V-III region NG9 (Fragment) & 2.151356 \\
\hline & & Ig heavy chain V-I region Mot & 0.849858 \\
\hline
\end{tabular}

replacement events on the NP surface regulated predominantly by the Vroman effect [61]. Therefore, it is possible to detect and discriminate different diseases based on diseases-specific protein corona pattern. NPs may show different colloidal stabilities in physiological fluids depending on the type of protein adsorbed to the surface. For example, proteins attached to the NP surface may decrease the surface charge and consequently neutralize electrostatic repulsion among NPs [62]. The protein corona may also act as a connector and link NPs to each other [63]. These types of protein coronas may increase NP agglomeration. In contrast, some proteins may increase the stability of NPs via increas- 
Table 6

Proteins only detected in the coronas of PEG-NPs obtained from $100 \%$ serums of AD and MS patients

\begin{tabular}{|c|c|c|c|}
\hline $\begin{array}{l}\text { Protein identity } \\
\text { (Corona coated PEG-NPs obtained after } \\
\text { incubation with } 100 \% \text { serum of AD cases) }\end{array}$ & $\mathrm{NSpC}$ & $\begin{array}{l}\text { Protein identity } \\
\text { (Corona coated PEG-NPs obtained after } \\
\text { incubation with } 100 \% \text { serum of MS cases) }\end{array}$ & $\mathrm{NSpC}$ \\
\hline Apolipoprotein B-100 & 0.159293 & Anoctamin-4 & 0.32462 \\
\hline Beta-2-glycoprotein 1 & 0.714875 & Interferon regulatory factor 2-binding protein 1 & 0.586538 \\
\hline Inter-alpha-trypsin inhibitor heavy chain $\mathrm{H} 2$ & 0.257154 & Olfactory receptor 52A 5 & 1.006359 \\
\hline CYP11B1 protein & 0.420367 & Tenomodulin & 0.974491 \\
\hline Glutamate receptor-interacting protein 1 & 0.223631 & DCN1-like protein (Fragment) & 1.540208 \\
\hline Insulin-like growth factor-binding protein 3 & 0.864359 & Kelch-like protein 11 & 0.451446 \\
\hline Heat shock protein $105 \mathrm{kDa}$ & 0.282637 & Dynein heavy chain 2 , axonemal & 0.071268 \\
\hline Pyruvate carboxylase, mitochondrial & 0.211194 & Cytochrome b-c1 complex subunit 1 , mitochondrial & 0.687286 \\
\hline C-C chemokine receptor type 7 & 0.638576 & & \\
\hline Armadillo repeat-containing X-linked protein 5 & 0.439123 & & \\
\hline Coiled-coil domain-containing protein 150 & 0.212622 & & \\
\hline $\begin{array}{l}\text { Peripheral-type benzodiazepine receptor- } \\
\text { associated protein } 1\end{array}$ & 0.136851 & & \\
\hline Ig heavy chain V-I region 5 (Fragment) & 2.14205 & & \\
\hline Enhancer of filamentation 1 & 0.294826 & & \\
\hline Plexin-B2 (Fragment) & 1.043972 & & \\
\hline Ubiquilin-4 & 0.428766 & & \\
\hline
\end{tabular}

Table 7

Proteins only detected in the coronas of PEG-NPs obtained from $10 \%$ serums of AD and MS patients

\begin{tabular}{|c|c|c|c|}
\hline $\begin{array}{l}\text { Protein identity } \\
\text { (Corona coated PEG-NPs obtained after } \\
\text { incubation with } 10 \% \text { serum of AD cases) }\end{array}$ & $\mathrm{NSpC}$ & $\begin{array}{l}\text { Protein identity } \\
\text { (Corona coated PEG-NPs obtained after } \\
\text { incubation with } 10 \% \text { serum of MS cases) }\end{array}$ & $\mathrm{NSpC}$ \\
\hline Ig heavy chain V-I region 5 & 3.734713 & Ig mu chain $\mathrm{C}$ region & 3.014587 \\
\hline Gelsolin & 0.556997 & Immunoglobulin lambda-like polypeptide 5 & 5.133242 \\
\hline N-terminal EF-hand calcium-binding protein 3 & 2.050352 & Proline-rich protein 11 & 0.988207 \\
\hline $\begin{array}{l}\text { Brefeldin A-inhibited guanine nucleotide- } \\
\text { exchange protein } 3\end{array}$ & 0.198353 & Ninein & 0.162846 \\
\hline Serotransferrin & 4.285257 & Immunoglobulin $\mathrm{J}$ chain & 2.18873 \\
\hline Alpha-2-HS-glycoprotein & 1.211148 & Structural maintenance of chromosomes protein 1B & 0.275262 \\
\hline \multirow[t]{2}{*}{ Fibrinogen alpha chain } & 0.502597 & Zinc finger protein ZIC 52 & 0.578732 \\
\hline & & SEC14-like protein 5 & 0.501794 \\
\hline
\end{tabular}

ing steric/entropic constancy [64]. Corona-coated $\mathrm{Au}$ NP complexes obtained from the serums of patients with different diseases have distinct protein composition and concentration. One may expect Au NPs to show different colloidal stability and agglomeration in different serums and thus exhibit variation in SPR intensity/peak position.

The concentration and structure of proteins involved in the corona play a crucial role in determining the colloidal stability of Au NPs $[65,66]$. For example, minor Au NP agglomeration was detected when NPs were incubated at high and low concentrations of hemoglobin $(\mathrm{Hb})$. In contrast, $\mathrm{Au}$ NP agglomeration considerably increased when a monolayer of $\mathrm{Hb}$ coated the NP surface. In this situation, $\mathrm{Hb}$ deactivated the electrostatic repulsion forces and/or connected the particles as a pons [65]. Protein unfolding can also affect NP colloidal stability. The unfolded Albumin caused Au NP aggregation [66]. Structural integrity and protein intensity of the corona governed colloidal stability of NPs in physiological media.

\section{Conclusion}

Changes in serum can accurately reflect the state and stage of disease in patients. It is, therefore, possible to detect disease type/progress on the basis of specific changes in composition of serum. Depending on the type and severity of disease, each patient may have distinct DSPC containing disease-specific biomarkers. Owing to the formation of DSPC, some proteins only appeared or disappeared in the corona of a particular disease and may be considered as a 
potential biomarker for indicating or predicting disease prevalence/progress or risk. The DSPC-Au NP complexes obtained from serums of different patients showed distinct array responses. The DSPC-based colorimetric technology fulfills the key requirements of sensitivity, specificity, facility, and affordability required for rapid and efficient diagnosis of diseases. The colorimetric technology developed in this study are able to discriminate and detect $\mathrm{AD}$ and MS on the basis of the DSPC. Further developments are, however, needed to improve the specificity and sensitivity of DSPC-based colorimetric technology.

\section{DISCLOSURE STATEMENT}

Authors' disclosures available online (http://j-alz. com/manuscript-disclosures/16-0206r3).

\section{SUPPLEMENTARY MATERIAL}

The supplementary material is available in the electronic version of this article: http://dx.doi.org/ 10.3233/JAD-160206.

\section{REFERENCES}

[1] Lynch I, Dawson KA (2008) Protein-nanoparticle interactions. Nano Today 3, 40-47.

[2] Cedervall T, Lynch I, Lindman S, Berggård T, Thulin E, Nilsson H, Dawson KA, Linse S (2007) Understanding the nanoparticle-protein corona using methods to quantify exchange rates and affinities of proteins for nanoparticles. Proc Natl Acad Sci U S A 104, 2050-2055.

[3] Mahmoudi M, Lynch I, Ejtehadi MR, Monopoli MP, Bombelli FB, Laurent S (2011) Protein-nanoparticle interactions: Opportunities and challenges. Chem Rev 111, 5610-5637.

[4] Del Pino P, Pelaz B, Zhang Q, Maffre P, Nienhaus GU, Parak WJ (2014) Protein corona formation around nanoparticles-from the past to the future. Mater Horiz 1, 301-313.

[5] Hajipour MJ, Akhavan O, Meidanchi A, Laurent S, Mahmoudi M (2014) Hyperthermia-induced protein corona improves the therapeutic effects of zinc ferrite spinel-graphene sheets against cancer. RSC $A d v \mathbf{4}$, 62557-62565.

[6] Monopoli MP, Åberg C, Salvati A, Dawson KA (2012) Biomolecular coronas provide the biological identity of nanosized materials. Nat Nanotechnol 7, 779-786.

[7] Lynch I, Salvati A, Dawson KA (2009) Protein-nanoparticle interactions: What does the cell see? Nat Nanotechnol 4, 546-547.

[8] Aggarwal P, Hall JB, McLeland CB, Dobrovolskaia MA, McNeil SE (2009) Nanoparticle interaction with plasma proteins as it relates to particle biodistribution, biocompatibility and therapeutic efficacy. Adv Drug Deliv Rev 61, 428-437.
[9] Mirshafiee V, Kim R, Park S, Mahmoudi M, Kraft ML (2016) Impact of protein pre-coating on the protein corona composition and nanoparticle cellular uptake. Biomaterials 75, 295-304.

[10] Tenzer S, Docter D, Kuharev J, Musyanovych A, Fetz V, Hecht R, Schlenk F, Fischer D, Kiouptsi K, Reinhardt C (2013) Rapid formation of plasma protein corona critically affects nanoparticle pathophysiology. Nat Nanotechnol $\mathbf{8}$, 772-781.

[11] Mahmoudi M, Sheibani S, Milani AS, Rezaee F, Gauberti M, Dinarvand R, Vali H (2015) Crucial role of the protein corona for the specific targeting of nanoparticles. Nanomedicine 10, 215-226.

[12] Hajipour MJ, Laurent S, Aghaie A, Rezaee F, Mahmoudi M (2014) Personalized protein coronas: A "key" factor at the nanobiointerface. Biomat Sci 2, 1210-1221.

[13] Caracciolo G (2015) Liposome-protein corona in a physiological environment: Challenges and opportunities for targeted delivery of nanomedicines. Nanomedicine 11, 543557.

[14] Caracciolo G, Caputo D, Pozzi D, Colapicchioni V, Coppola R (2014) Size and charge of nanoparticles following incubation with human plasma of healthy and pancreatic cancer patients. Colloids Surf B Biointerfaces 123, 673-678.

[15] Hye A, Lynham S, Thambisetty M, Causevic M, Campbell J, Byers H, Hooper C, Rijsdijk F, Tabrizi S, Banner S (2006) Proteome-based plasma biomarkers for Alzheimer's disease. Brain 129, 3042-3050.

[16] Song F, Poljak A, Crawford J, Kochan NA, Wen W, Cameron B, Lux O, Brodaty H, Mather K, Smythe GA (2012) Plasma apolipoprotein levels are associated with cognitive status and decline in a community cohort of older individuals. PLoS One 7, e34078.

[17] Hye A, Riddoch-Contreras J, Baird AL, Ashton NJ, Bazenet C, Leung R, Westman E, Simmons A, Dobson R, Sattlecker M (2014) Plasma proteins predict conversion to dementia from prodromal disease. Alzheimers Dement 10, 799-807. e792.

[18] Licastro F, Pedrini S, Davis LJ, Caputo L, Tagliabue J, Savorani G, Cucinotta D, Annoni G (2001) $\alpha-1$ antichymotrypsin and oxidative stress in the peripheral blood from patients with probable Alzheimer disease: A short-term longitudinal study. Alzheimer Dis Assoc Disord 15, 51-55.

[19] Liu Y, Qing H, Deng Y (2014) Biomarkers in Alzheimer's disease analysis by mass spectrometry-based proteomics. Int J Mol Sci 15, 7865-7882.

[20] Llano DA, Devanarayan V, Simon AJ, Alzheimer's Disease Neuroimaging Initiative (ADNI) (2013) Evaluation of plasma proteomic data for Alzheimer disease state classification and for the prediction of progression from mild cognitive impairment to Alzheimer disease. Alzheimer Dis Assoc Disord 27, 233-243.

[21] Genain CP, Cannella B, Hauser SL, Raine CS (1999) Identification of autoantibodies associated with myelin damage in multiple sclerosis. Nat Med 5, 170-175.

[22] Boz C, Oger J, Gibbs E, Grossberg S (2007) Reduced effectiveness of long-term interferon- $\beta$ treatment on relapses in neutralizing antibody-positive multiple sclerosis patients: A Canadian multiple sclerosis clinic-based study. Mult Scler 13, 1127-1137.

[23] Ascherio A, Munger KL (2007) Environmental risk factors for multiple sclerosis. Part I: The role of infection. Ann Neurol 61, 288-299. 
[24] Wallin M, Oh U, Nyalwidhe J, Semmes J, Kislinger T, Coffman P, Kurtzke J, Jacobson S (2015) Serum proteomic analysis of a pre-symptomatic multiple sclerosis cohort. Eur J Neurol 22, 591-599.

[25] Benilova I, Karran E, De Strooper B (2012) The toxic A [beta] oligomer and Alzheimer's disease: An emperor in need of clothes. Nat Neurosci 15, 349.

[26] Hajipour MJ, Raheb J, Akhavan O, Arjmand S, Mashinchian O, Rahman M, Abdolahad M, Serpooshan V, Laurent S, Mahmoudi M (2015) Personalized disease-specific protein corona influences the therapeutic impact of graphene oxide. Nanoscale 7, 8978-8994.

[27] Nestor PJ, Scheltens P, Hodges JR (2004) Advances in the early detection of Alzheimer's disease. Nat Rev Neuro 5, S34-S41.

[28] Kuhlmann T, Lingfeld G, Bitsch A, Schuchardt J, Brück W (2002) Acute axonal damage in multiple sclerosis is most extensive in early disease stages and decreases over time. Brain 125, 2202-2212.

[29] Confavreux C, Vukusic S, Moreau T, Adeleine P (2000) Relapses and progression of disability in multiple sclerosis. $N$ Engl J Med 343, 1430-1438.

[30] Yachida S, Jones S, Bozic I, Antal T, Leary R, Fu B, Kamiyama M, Hruban RH, Eshleman JR, Nowak MA (2010) Distant metastasis occurs late during the genetic evolution of pancreatic cancer. Nature 467, 1114-1117.

[31] Petricoin EF, Belluco C, Araujo RP, Liotta LA (2006) The blood peptidome: A higher dimension of information content for cancer biomarker discovery. Nat Rev Cancer 6, 961-967.

[32] Chen X, Ba Y, Ma L, Cai X, Yin Y, Wang K, Guo J, Zhang Y, Chen J, Guo X (2008) Characterization of microRNAs in serum: A novel class of biomarkers for diagnosis of cancer and other diseases. Cell Res 18, 997-1006.

[33] Blennow K, Hampel H, Weiner M, Zetterberg H (2010) Cerebrospinal fluid and plasma biomarkers in Alzheimer disease. Nat Rev Neurol 6, 131-144.

[34] Mapstone M, Cheema AK, Fiandaca MS, Zhong X, Mhyre TR, MacArthur LH, Hall WJ, Fisher SG, Peterson DR, Haley JM (2014) Plasma phospholipids identify antecedent memory impairment in older adults. Nat Med 20, 415-418.

[35] Viola KL, Sbarboro J, Sureka R, De M, Bicca MA, Wang J, Vasavada S, Satpathy S, Wu S, Joshi H (2015) Towards non-invasive diagnostic imaging of early-stage Alzheimer's disease. Nat Nanotechnol 10, 91-98.

[36] Madasamy S, Chaudhuri V, Kong R, Alderete B, Adams CM, Knaak TD, Ruan W, Wu AH, Bigos M, Amento EP (2015) Plaque array method and proteomics-based identification of biomarkers from Alzheimer's disease serum. Clin Chim Acta 441, 79-85.

[37] Guo L-H, Alexopoulos P, Wagenpfeil S, Kurz A, Perneczky R, Alzheimer's Disease Neuroimaging Initiative (2013) Plasma proteomics for the identification of Alzheimer's disease. Alzheimer Dis Assoc Disord 27, 337-342,

[38] Tremlett H, Dai DL, Hollander Z, Kapanen A, Aziz T, Wilson-McManus JE, Tebbutt SJ, Borchers CH, Oger J, Freue GVC (2015) Serum proteomics in multiple sclerosis disease progression. J Proteomics 118, 2-11.

[39] Ghasemi F, Hormozi-Nezhad MR, Mahmoudi M (2015) A colorimetric sensor array for detection and discrimination of biothiols based on aggregation of gold nanoparticles. Anal Chim Acta 882, 58-67.

[40] Lin H, Suslick KS (2010) A colorimetric sensor array for detection of triacetone triperoxide vapor. $\mathrm{J} \mathrm{Am} \mathrm{Chem} \mathrm{Soc}$ 132, 15519-15521.
[41] Feng L, Musto CJ, Kemling JW, Lim SH, Suslick KS (2010) A colorimetric sensor array for identification of toxic gases below permissible exposure limits. Chem Commun 46, 2037-2039.

[42] Lim SH, Feng L, Kemling JW, Musto CJ, Suslick KS (2009) An optoelectronic nose for the detection of toxic gases. Nat Chem 1, 562-567.

[43] Askim JR, Mahmoudi M, Suslick KS (2013) Optical sensor arrays for chemical sensing: The optoelectronic nose. Chem Soc Rev 42, 8649-8682.

[44] Rakow NA, Suslick KS (2000) A colorimetric sensor array for odour visualization. Nature 406, 710-713.

[45] Mahmoudi M, Bertrand N, Zope H, Farokhzad OC (2016) Emerging understanding of the protein corona at the nanobio interfaces. Nano Today 11, 817-832.

[46] Kimling J, Maier M, Okenve B, Kotaidis V, Ballot H, Plech A (2006) Turkevich method for gold nanoparticle synthesis revisited. J Phys Chem B 110, 15700-15707.

[47] Mahmoudi M, Shokrgozar MA, Behzadi S (2013) Slight temperature changes affect protein affinity and cellular uptake/toxicity of nanoparticles. Nanoscale 5, 3240-3244.

[48] Bigdeli A, Palchetti S, Pozzi D, Hormozi-Nezhad MR, Baldelli Bombelli F, Caracciolo G, Mahmoudi M (2016) Exploring cellular interactions of liposomes using protein corona fingerprints and physicochemical properties. ACS Nano 10, 3723-3737.

[49] Almeida J, Barbosa L, Pais A, Formosinho S (2007) Improving hierarchical cluster analysis: A new method with outlier detection and automatic clustering. Chemometr Intell Lab Syst 87, 208-217.

[50] Bro R, Smilde AK (2014) Principal component analysis. Anal Methods 6, 2812-2831.

[51] Fiorini A, Koudriavtseva T, Bucaj E, Coccia R, Foppoli C, Giorgi A, Schininá ME, Di Domenico F, De Marco F, Perluigi M (2013) Involvement of oxidative stress in occurrence of relapses in multiple sclerosis: The spectrum of oxidatively modified serum proteins detected by proteomics and redox proteomics analysis. PLoS One $\mathbf{8}$, e65184.

[52] Villoslada P (2010) Biomarkers for multiple sclerosis. Drug News Perspect 23, 585-595.

[53] Tomioka R, Matsui M (2014) Biomarkers for multiple sclerosis. Intern Med 53, 361-365.

[54] Zabel M, Schrag M, Mueller C, Zhou W, Crofton A, Petersen F, Dickson A, Kirsch WM (2012) Assessing candidate serum biomarkers for Alzheimer's disease: A longitudinal study. J Alzheimers Dis 30, 311-321.

[55] Han S-H, Jung ES, Sohn J-H, Hong HJ, Hong HS, Kim JW, Na DL, Kim M, Kim H, Ha HJ (2011) Human serum transthyretin levels correlate inversely with Alzheimer's disease. J Alzheimers Dis 25, 77-84.

[56] Dursun E, Gezen-Ak D, Hanağasi H, Bilgiç B, Lohmann E, Ertan S, Atasoy IL, Alaylioğlu M, Araz ÖS, Önal B (2015) The interleukin 1 alpha, interleukin 1 beta, interleukin 6 and alpha-2-macroglobulin serum levels in patients with early or late onset Alzheimer's disease, mild cognitive impairment or Parkinson's disease. J Neuroimmunol 283, 50-57.

[57] Doecke JD, Laws SM, Faux NG, Wilson W, Burnham SC, Lam C-P, Mondal A, Bedo J, Bush AI, Brown B (2012) Blood-based protein biomarkers for diagnosis of Alzheimer disease. Arch Neurol 69, 1318-1325.

[58] Rasmussen KL, Tybjærg-Hansen A, Nordestgaard BG, Frikke-Schmidt R (2015) Plasma levels of apolipoprotein E and risk of dementia in the general population. Ann Neurol 77, 301-311. 
[59] Colapicchioni V, Tilio M, Digiacomo L, Gambini V, Palchetti S, Marchini C, Pozzi D, Occhipinti S, Amici A, Caracciolo G (2015) Personalized liposome-protein corona in the blood of breast, gastric and pancreatic cancer patients. Int J Biochem Cell Biol 75, 180-187.

[60] Caputo D, Papi M, Coppola R, Palchetti S, Digiacomo L, Caracciolo G, Pozzi D (2017) A protein coronaenabled blood test for early cancer detection. Nanoscale $\mathbf{9}$, 349-354.

[61] Vroman L (1962) Effect of adsorbed proteins on the wettability of hydrophilic and hydrophobic solids. Nature 196, 476-477.

[62] Chanana M, Correa-Duarte MA, Liz-Marzán LM (2011) Insulin-coated gold nanoparticles: a olasmonic device for studying metal-protein interactions. Small 7, 2650-2660.
[63] Bharti B, Meissner J, Findenegg GH (2011) Aggregation of silica nanoparticles directed by adsorption of lysozyme. Langmuir 27, 9823-9833.

[64] Chanana M, Rivera_Gil P, Correa-Duarte MA, Liz-Marzán LM, Parak WJ (2013) Physicochemical properties of protein-coated gold nanoparticles in biological fluids and cells before and after proteolytic digestion. Angew Chem Int Ed Engl 52, 4179-4183.

[65] Moerz ST, Kraegeloh A, Chanana M, Kraus T (2015) Formation mechanism for stable hybrid clusters of proteins and nanoparticles. ACS Nano 9, 6696-6705.

[66] Dominguez-Medina S, Kisley L, Tauzin LJ, Hoggard A, Shuang B, DS Indrasekara AS, Chen S, Wang L-Y, Derry PJ, Liopo A (2016) Adsorption and unfolding of a single protein triggers nanoparticle aggregation. ACS Nano $\mathbf{1 0}$, 2103-2112. 